\title{
Properties and potential of agarwood hydrosol as a drink: a review
}

\author{
${ }^{1}$ Mohamad Kahar, E.E., ${ }^{1}$ Talip, B.A., ${ }^{2}$ Mohd Fauzi, N.A., ${ }^{1}$ Kamarulzaman, S.N., \\ ${ }^{1}$ Zakaria, F., ${ }^{1}$ Muhammad, N., ${ }^{2}$ Rajat Mamat, T.N.A. and ${ }^{1}$ Basri, H. \\ ${ }^{1}$ Faculty of Applied Sciences and Technology, Universiti Tun Hussein Onn Malaysia, Pagoh Higher \\ Education Hub, KM 1, Jalan Panchor, 84600, Panchor, Johor \\ ${ }^{2}$ Faculty of Engineering Technology, Universiti Tun Hussein Onn Malaysia, Pagoh Higher Education Hub, \\ KM 1, Jalan Panchor, 84600, Panchor, Johor
}

\begin{abstract}
Article history:
Received: 24 July 2020

Received in revised form: 6 September 2020

Accepted: 31 October 2020 Available Online: 28 March 2021
\end{abstract}

\section{Keywords:}

Agarwood,

Hydrosol,

Extraction,

Essential oil,

Drink

DOI:

https://doi.org/10.26656/fr.2017.5(3).382

\begin{abstract}
Agarwood is resinous valuable heartwood of Aquilaria tree resulting from self-defence mechanism towards injuries or damages exerted on the tree. Agarwood essential oil is usually extracted through a process of hydrodistillation or steam distillation which is beneficial for commercial purposes such as perfumeries and cosmetics. Hydrosol, a byproduct of the process produced in abundance and underutilized particularly in the agarwood industry. Hydrosol of agarwood is an aromatic compound that is believed to have chemical properties similar to essential oils that consist of positive antioxidant activity and positive biological activity for living cells. Several studies on properties of hydrosol of agarwood show that it contained zero nutrient but varied with minerals in the appropriate proportion that safe for human consumption. Thus, this review was aimed to discuss the agarwood hydrosol processing methods, characteristics, antioxidants properties and its comparisons to other plants hydrosol that have been commercially used as human consumption as in flavoured and non-flavoured beverages.
\end{abstract}

\section{Introduction}

Agarwood is the resinous, fragrant and highly valuable heartwood produced by Aquilaria tree or known as Karas in Malay. There are several species of Aquilaria grown or cultivated in many regions in Asia such as $A$. malaccensis, A. grandiflora, A. rostrata, A. hirta, A. microcapa, A. sinensis, A. filaria and A. subintegra (Elias et al., 2017). Agarwood-producing species can be found in areas ranging from India to the east, throughout Southeast Asia, including southern China. However, Indonesia and Malaysia are reported as the country of origin of this agarwood-producing species (Liu et al., 2013). The physical characteristics of a healthy Aquilaria tree are its soft trunk and light colour. If the tree is exposed to parasitic or pathogen infection, it will produce a resin that will cause the infected tissue of the trees to turn darker in colour (Chua, 2008).

Naturally, the formation of agarwood resin is often associated with physical injuries or damage caused by disease and pest attacks (Wu et al., 2017). Fungal inoculation is also a method that promotes the formation of agarwood which is proven to be safe handle and also does not have a significant impact on the environment.
Chemical inoculation usually contains a variety of ingredients including salts, vinegar, salicylic acid and yeast extract that can only be used according to a certain dosage. This is to avoid extreme damage to the tissue of the tree and further damage the area that has formed agarwood (Azren et al., 2019). In Southeast Asia, Aquilaria planters usually injure trees by nailing the tree trunks, perforating, burning or pruning the tree trunks (Liao et al., 2018). These mechanical methods will expose the internal part of the trees to pathogenic microbes as a result of defence mechanism that triggers the resin production which is agarwood.

Agarwood, especially its essential oil and wood core, has a high market value depending on the quality which is usually determined by customer demand. The usual parameters used in determining the price of essential oils are based on colour and smell and are sold at a price of USD 50 to USD 500 per tola $(12 \mathrm{~mL}$ ) (Nor Azah et al., 2008). In addition, the global minimum price for wood and wood chips is around USD 20 to USD 6000 per kilogram depending on its quality. Good and potential wood has a high price depending on the size of the resin formation on the core and the odour that lasts longer 
when it is burned. A study by Ismail et al. (2014) have shown that quality of agarwood essential oil is dependent on physical properties of wood, colour, resin content, long-lasting aroma when burned, high fixative properties and consumer perception. In addition, several other studies have stated that high quality agarwood essential oil must contain several compounds such as, $\beta$ agarofuran, $\quad \alpha$-agarofuran, $\quad 10-$-epi- $\gamma$-eudesmol, $\quad \alpha-$ eudesmol, dihydrocollumellarin, $\quad \gamma$-eudesmol, agarospirol and aromadendrane (Kalra and Kaushik, 2017).

In addition to primary products such as essential oils and wood, agarwood can also produce secondary products resulting from the processing of essential oils known as hydrosol. Hydrosol is known as hydrolates, distillate water and aromatic water resulting in byproducts of plant distillation processes, either by hydrodistillation or steam distillation. Hydrosol contains water-soluble components and may consist of a trace amount of plant essential oils components (Hussein et al., 2019). This by-product is usually colourless and acidic depending on the type of plant being distilled. Agarwood hydrosol is usually produced by hydrodistillation method. Wood chips will be crushed into the smallest particles and mixed with water at a ratio $(1: 10, \mathrm{w} / \mathrm{v})$ (Sulaiman et al., 2015) and undergo a process of hydrodistillation for three (3) to seven (7) days to obtain essential oils and hydrosol in the same process. This by-product is usually colourless and acidic depending on the type of plant being distilled. Agarwood hydrosol usually produced by hydrodistillation method. Wood chips will be crushed into the smallest particles and mixed with water at ratio $(1: 10, \mathrm{w} / \mathrm{v})$ (Sulaiman et al., 2015) and undergo a process hydrodistillation for three (3) to seven (7) days to obtain essential oils and hydrosol in the same process. In the process of extracting agarwood essential oil, hydrosols will be produced in large quantities and are usually discarded. This may be due to very limited studies regarding the uses and advantages of agarwood hydrosol compared to its other extract products. Compared to essential oil products, hydrosol is easier to produce from this hydrodistillation process. Therefore, this study aims to look at the hydrosol properties of agarwood resulting from the essential oil extraction process that may be suitable as a drink or can be formulated into a flavoured beverage for human consumption.

\section{Hydrosol in industry}

There are several common hydrosols sold globally such as rose, lavender, peppermint and lemon. Hydrosol which produced by the process of hydro distillation is abundance and consider as an underutilized by-product (Rao, 2012). Although it has been used in cosmetic making such as toner, fragrant mist and SPA-bath, hydrosol still not the preferred choice in the cosmetics and nutraceutical manufacturing industry as its study is not significant compared to agarwood essential oil (Che Radzi et al., 2018). Although some studies have reported on the presence of physicochemical in hydrosol, the limited number of studies makes this by-product less used in the agarwood industry.

It has been stated that the chemical properties of hydrosol may have similar properties to essential oil. Preliminary data indicate that essential oil from Aquilaria sp. contains 10-epi- $\gamma$-eudesmol, guaiol acetate and $\beta$-selinine. These compounds can contribute to the presence of sesquiterpenes. Sesquiterpenes act as a secondary metabolite that can produce healing properties. In addition, it is also the phenolic compounds associated with antioxidant activity due to free radical scavengers.

The tendency to over-claim the advantages of a plant -based product is common among manufacturers and the community. Referring to the NPRA regulation, it has been stated that drink or food product shall not be claimed as a natural product unless it has been proven through laboratory tests. The stigma of believing in "natural products" in society has led to the development of food and beverage products based on natural ingredients becoming more important. However, the diversity of compounds, whether or not scientifically identifiable in this "natural" label is one of the challenges in verifying the advantages to its users. Thus, scientific research on the advantages of a product is encouraged to provide authentic information to consumers. Sensory evaluation is one of the methods that can be used to see user acceptance of a product (Lange et al., 2002). Hydrosol is commonly sold as a substance in cosmetics, sanitizing agent and aromatherapeutics. According to amazon.com, the market price for hydrosol is around USD 13 for $120 \mathrm{~mL}$ hydrosol products. However, the price depends on the type of plant and the quantity. There are various types of hydrosols sold worldwide in addition to agarwood hydrosols. Among the easily available in the market are rose water, spice hydrosol, herbal hydrosol and fruit hydrosol (Lante and Tinello, 2015). Although agarwood hydrosol is available in the local market, its sales are still limited. This may be due to a lack of research on the safety of its use.

\section{The extraction of essential oil using hydro distillation process}

The extraction of essential oil is vital in gaining the 
good quality essential oil. Compared to essential oils originate from herbs and flowers, agarwood essential oil has a higher market price. This is because the resin formation in young trees (less than 10 years) barely occurs. In addition, the low yield of essential oil during extraction is also a factor in its high price in the market (Sulaiman et al., 2015). Through a complete hydro distillation system and pre-treatment of wood, 20 kilograms of agarwood powder can only produce less than $20 \mathrm{~mL}$ of essential oil (Jok et al., 2015). There are several methods of plant extraction to obtain essential oil (Table 1). The most preferable method in extracting essential oil from agarwood is hydrodistillation. It is because of its easy, effective and low-cost processing compared to other extraction methods. Hydro distillation gives the best condition of extraction for powders or tough materials like wood or roots because the plant material is immersed completely in the water. The water that surrounds the plant material may act as a barrier to prevent overheating or charring (Kusuma and Mahfud, 2016).

The advantage of utilizing this method is less steam is being used (Table 2). In distillation, there is a cycle or flow of process involved. The plant material is heated, by placing it in water which subsequently brought to the boil. The heat causes the cell structure of the plant material to burst and break down, freeing the essential oils. The essential oil molecules and steam will carry along a pipe and channelled through a cooling tank, where its return to liquid form as condensation process occurs that is from gas to liquid and collected in a vat. The emerging liquid is a mixture of oil and water, and since essential oils are not water-soluble and low density, they can easily be separated from the water and siphoned off.

The steam distillation extraction indicates that the plant sample will be directly served with hot steam. Hence, the plant material will be exhausted with dry steam only when all the volatile oil released from the oilbearing cells. The hot steam may cause burn and overheating to the plant material (Asbahani et al., 2015). Solvent extraction may cause the product to form crude extract which the essential oil will be mixed with other compound and undergo chemical modifications that can spoil the food and fragrances when added with it (Faborode and Favier, 1996). Solvent extraction by using methanol, ethanol and water is widely used to extract desired agarwood chemical compound to test the pharmacological effect on certain diseases or as herbal medicines, not as a method to extract essential oil (Zakaria et al., 2020). In addition, the heat transfer of hydro distillation method provides heat from outside to the inside, due to the conduction and convection that happen through the water surrounding the plant material and heat supply (Bayramoglu et al., 2008).

Microwave-assisted extraction (MAE) and solventfree microwave-assisted extraction (SFME) are believed

Table 1. Research studies on extraction method of plants to obtain essential oil

\begin{tabular}{lll}
\hline Extraction & Example of plant & References \\
\hline Hydrodistillation & Coriander & Zheljazkov et al. (2014) \\
& Agarwood & Pornpunyapat et al. (2011), Samadi et al. (2017) \\
\hline Steam distillation & Sage & Baydar et al. (2013) \\
& Rose & Demirbolat et al. (2019) \\
\hline Solvent extraction & Labile plant such as blossom & Stratakos and Koidis (2016) \\
\hline Microwave-assisted extraction (MAE) & Sandalwood & Kusuma and Mahfud (2016) \\
\hline Solvent-free microwave extraction (SFME) & Oregano & Bayramoglu et al. (2008) \\
\hline
\end{tabular}

Table 2. Comparison between different types of plant extraction

\begin{tabular}{cccc}
\hline Hydrodistillation & Steam distillation & Solvent extraction & $\begin{array}{c}\text { Microwave-assisted } \\
\text { extraction (MAE) }\end{array}$ \\
\hline $\begin{array}{c}\text { Plant material immersed } \\
\text { completely in water }\end{array}$ & $\begin{array}{c}\text { Plant material not completely } \\
\text { immersed in water }\end{array}$ & $\begin{array}{c}\text { Plant material immersed } \\
\text { completely in chemical or } \\
\text { solvent }\end{array}$ & $\begin{array}{c}\text { Plant material immersed in } \\
\text { solvent or water }\end{array}$ \\
\hline $\begin{array}{c}\text { Water surrounding the plant } \\
\text { material }\end{array}$ & $\begin{array}{c}\text { Steam surrounding the plant } \\
\text { material }\end{array}$ & $\begin{array}{c}\text { Solvent surrounding the plant } \\
\text { material }\end{array}$ & $\begin{array}{c}\text { Solvent or water surrounding } \\
\text { the plant material }\end{array}$ \\
\hline $\begin{array}{c}\text { Does not pollute products } \\
\text { especially food }\end{array}$ & $\begin{array}{c}\text { Does not pollute products } \\
\text { especially food }\end{array}$ & $\begin{array}{c}\text { May pollute the food and } \\
\text { fragrances added }\end{array}$ & Not applicable \\
\hline $\begin{array}{c}\text { No overheating and charring } \\
\text { Oconomic }\end{array}$ & $\begin{array}{c}\text { Overheating, burnt } \\
\text { but formed crude extract }\end{array}$ & No overheating and charring \\
\hline Industrial scale & Economic & $\begin{array}{c}\text { High usage of solvent or } \\
\text { chemical }\end{array}$ & Not economic \\
hydrosol & Industrial scale & Laboratory scale & Laboratory scale \\
\hline Produce essential oil and & Produce essential oil and & $\begin{array}{c}\text { Essential oil mix with other } \\
\text { compounds of plant material, } \\
\text { no hydrosol produced }\end{array}$ & Not applicable \\
\end{tabular}


can extract essential oil rapidly as both are innovative techniques which can extract essential oil in shorter times, low solvent consumption and low energy input. However, this method is impractical for industrial-scale due to lack of technological readiness for a large-scale application (Asbahani et al., 2015).

\section{The properties of hydrosol}

The aqueous water that forms during the essential oil extraction of the aromatic plant is known as hydrosol. Hydrosol is highly dilute acidic (pH 3.5-6.5) and this produces a mild or pleasant-scented emulsion. The $\mathrm{pH}$ may vary based on to plant types as tabulated in Table 3 . The hydrosol odour may vary from mild to strong, pleasant to unpleasant and similar to dissimilar to the essential oil extracted depending on the time of collection during distillation (Rao, 2012). Hydrosols collected during the early part of distillation are pleasantscented and it considered as therapeutically more useful than the entire distillation water. In contrast, hydrosol collected during the latter part of distillation consists of different components that brought out by low or high boiling terpenoids present in the hydrosols (Rao, 2012). Detection of coliforms bacteria in hydrosols of Lamiaciae, Pinaceae and Asteracea plant are almost 0 which is below accepted value for drinking water, $>5$ $\mathrm{CFU} / 100 \mathrm{~mL}$. Thus, this shows that hydrosols are free from microorganism and safe for human consumption (Garneau et al., 2014).

Table 3. $\mathrm{pH}$ of different kinds of plant hydrosol

\begin{tabular}{lll}
\hline Name of plant & $\mathrm{pH}$ & References \\
\hline P. graveolens & $4.5-5.5$ & Babu and Kaul (2005) \\
A. malaccensis & $3.15-4.53$ & Abdullah and Moosa (2010) \\
S. hortensis L. & 3.8 & Abdullah and Moosa (2010) \\
T. vulgaris L. & 4.0 & Sagdic et al. (2013) \\
O. onites L. & 4.3 & Sagdic et al. $(2013)$ \\
P. glauca & 3.85 & Sagdic et al. (2013) \\
S. puberula & $3.6-4.1$ & Garneau et al. (2014) \\
M. piperita & 5.2 & Garneau et al. (2014) \\
\hline
\end{tabular}

\section{Hydrosol as a component in making ready-to- drink product}

Hydrosol is a by-product of aromatic plants during the distillation process. It is not obtained from a process of boiling, blanching or immersing of agarwood powder. Several studies have been conducted to determine the benefits and safeness of plant hydrosol for human consumption as tabulated in Table 4. A previous study has stated that hydrosol of sage (Salvia officinalis) distillation has been used in making of hydrosol flavoured drink (Baydar et al., 2013). Salvia (Salvia officinalis), is a member of Lamiaceae family and has the medicinal properties. Although extraction products like absolute and hydrosol from the oil of sage have an economical interest, there are very limited studies according to these products.

In Turkey, hydrosol of plants that consist of medicinal properties is used for herbal drink and act as a natural antibiotic which gives properties against various bacterial diseases and also aids indigestion. Hydrosol from its chemical properties may contain a part of the essential oil that indicates to have the same properties as an essential oil.

The Iranian consume hydrosols as natural drinks with the addition of natural sweeteners such as sugar or honey while Persian community believed that hydrosol is a beneficial beverage for human consumption due to its medicinal properties depending on the type of the plants used (Hamedi et al., 2017). Persian and Iranian also stated that hydrosol has moderate biological activity. It could be due to the constituent of hydrosol, which is balanced by the water in it with its water-soluble volatile compounds compared to a pure essential oil (Rose, 1999; Catty, 2001). In addition, natural essential oils have a stronger taste and are not recommended to be drunk or eaten directly. Thus, in order to obtain similar benefits as essential oils in drinks or beverages, hydrosol may potentially be used and formulated to make flavoured beverages.

\section{Antioxidant activity and biological activity of Agarwood}

Antioxidants are chemical compounds that reacts towards free radicals and neutralize it for preventing cell damage. According to the National Cancer Institute, the body also may produce the antioxidants to neutralize the

Table 4. Studies on the use of plant hydrosol as human consumption

\begin{tabular}{lc}
\hline \multicolumn{1}{c}{ Key points } & References \\
\hline $\begin{array}{l}\text { Hydrosol has been used in traditional medicine in Mediterranean countries as refreshing drinks and } \\
\text { flavourings. }\end{array}$ & D'Amato et al. (2018) \\
\hline Iranian culture diluted hydrosol at ratio 1:8 or 1:2 with water to consume as beverages. & D'Amato et al. (2018) \\
\hline Spices hydrosol may act as antimicrobial agents to prevent deterioration of the food. & Sağdiç and Özcan (2002) \\
\hline $\begin{array}{l}\text { Iranian culture processed oriental plane hydrosol and dill hydrosol as soft drink beverage because it } \\
\text { believed the hydrosols are hypotensive and may act as a hypolipidemic agent but not commercially } \\
\text { presented to the world of the market. }\end{array}$ & Hamedi et al. (2017) \\
\hline
\end{tabular}

Cinnamon hydrosol is safe as human consumption in dilution form at $0.5 \%$ hydrosol concentration as no death rate on carp fish towards the hydrosol.

Gulec et al. (2013) 
free radical that forms inside the body. The antioxidant that forms by the body called endogenous antioxidants. However, the internal antioxidant will not be sufficient to neutralize the radical forms, hence the body also relies on the external or exogenous antioxidants. Exogenous antioxidants sources from the fruits, vegetable, grains or herbal that human consumes to obtain more antioxidants. Some dietary antioxidants are also available as dietary supplements approved by the Food Drug Administration (FDA).

The benefit of using natural products that contain antioxidants are due to the low toxicity, an unusual mixture of multiple antioxidants in the product, ability to react to most or all types of ROS, and accessible to find. For instance, for the drink that has the highest amount of antioxidants is an herbal tea which is one of the most popular and widely consumed as non-alcoholic beverages among the types of natural products (Trevisanato and Kim, 2000). Moreover, the protective effect of these herbal teas against oxidative stress will be due to the presence of polyphenols compound. The phenolic compound is considered as the secondary metabolites, which give the healing properties of the plants. Hence, it may have the properties for free radical scavenging which can prevent several diseases (Wojdyło et al., 2007). Antioxidant activity of agarwood can be measured based on radical scavenging activity and phytochemical properties such as total phenolic content and total flavonoid content.

A study by Abdullah and Moosa (2010) from Malaysian Nuclear Agency (ANM) showed that total phenolic content of several samples of agarwood hydrosol from the different factory is range from 10.25 to $17.35 \mathrm{GAE} / \mathrm{mL}$ while radical scavenging activity by using DPPH assay and ABTS assay is range from 2.31 to $2.72 \%$ inhibition and 0.465 to $0.56 \mathrm{mmol}$ Trolox $/ \mathrm{mL}$ respectively. This value has shown present of antioxidant activity in hydrosol of agarwood but lower than standard control value (Abdullah and Moosa, 2010). Hydrosol of agarwood is capable to act as anti-metastatic based on cytotoxicity assay that has been made against Calu-3 lung cancer cells. The rate of cell death is depending on different concentration of hydrosol and exposure duration of cancer cell towards hydrosol as low as $50 \mu \mathrm{l} /$ $\mathrm{mL}$ within 12 hours exposure. This may be due to agarwood hydrosol able to change the enzymatic activity of cell mitochondria and initiate primary injury that accelerate cell death (Hussein et al., 2019).

Agarwood consists of a variety of chemical compounds which promotes positive biological activity to living cell (Chen et al., 2012). In vitro analysis by using MTT assay showed antitumor activity between human gastric cancer cell line with 2-(2-Phenylethyl)4H-chromen-4-one derivative extracted from $A$. sinensis. Meanwhile, the extract of AcOEt from the heartwood of $A$. agallocha showed a high antioxidant effect on human blood haemolysate when undergoing in vitro analysis (Chen et al., 2012). On the other hand, agarwood leaves are known to contain hydrocarbon, terpenes and esters such as n-hexadecenoic acid, hexadecanoid acid and 2-hydroxy-1- (hydroxymethyl) ethyl ester (Zainurin et al., 2020). Hypoglycemic effect testing on diabetic mice/rats exhibits strong glucosidase inhibitory activity of the compounds that act as an antidiabetic agent, which reduce blood glucose level (Adam et al., 2017).

\section{Conclusion}

The underutilized of hydrosol from agarwood hydro distillation process can be used to produce a new consumable product that safe for human consumption and give beneficial effect to consumers. This is because agarwood hydrosol is by-product produced from water or steam distillation of plant materials which free from any chemical substances during the extraction process. The enrichment of the hydrosol by nutritious ingredient may contribute to the improvement of nutritive value particularly in antioxidant properties. Agarwood hydrosol might contain traces amount of chemical component that similar to agarwood essential oil which beneficial for medicinal and pharmaceutical purposes. Further studies need to be done to validate the relationship of the chemical compound in agarwood essential oil with the chemical compound of raw hydrosol that may potentially aid in pharmacological aspects.

\section{Conflict of interest}

The authors declare no conflict of interest.

\section{Acknowledgement}

The authors wish to thank the Universiti Tun Hussein Onn Malaysia under Geran Penyelidikan Pasca Siswazah (GPPS Vot No. H549), Research Fund, UTHM, Pejabat Penerbit UTHM, Agarwood Technologies Plantation Sdn. Bhd. and Centre of Research Sustainable Uses of Natural Resources (CoSUNR) for supporting this research.

\section{References}

Abdullah, N.H.L. and Moosa, S. (2010). Characterisation of gaharu hydrosol: Physical, chemical and microbiological properties presented at $\mathrm{RnD}$ Seminar 2010: Research and Development Seminar 2010. 
Malaysia

Adam, A.Z., Lee, S.Y. and Mohamed, R. (2017). Pharmacological properties of agarwood tea derived from Aquilaria (Thymelaeaceae) leaves: An emerging contemporary herbal drink. Journal of Herbal Medicine, 10, 37-44. https://doi.org/10.1016/ j.hermed.2017.06.002

Asbahani, A. El, Miladi, K., Badri, W., Sala, M., Addi, E.H.A., Casabianca, H., Mousadik, A.El, Hartmann, D., Jilale, A., Renaud, F.N. and Elaissari, A. (2015). Essential oils: From extraction to encapsulation. International Journal of Pharmaceutics, 483(1-2), 220-243.

j.ijpharm.2014.12.069

Azren, P.D., Lee, S. Y., Emang, D. and Mohamed, R. (2019). History and perspectives of induction technology for agarwood production from cultivated Aquilaria in Asia: a review. Journal of Forestry Research, 30(1), 1-11. https://doi.org/10.1007/ s11676-018-0627-4

Babu, K.G.D. and Kaul, V.K. (2005). Variation in essential oil composition of rose-scented geranium (Pelargonium sp.) distilled by different distillation techniques. Flavour and Fragrance Journal, 20(2), 222-231. https://doi.org/10.1002/ffj.1414

Baydar, H., Sangun, M.K., Erbas, S. and Kara, N. (2013). Comparison of Aroma Compounds in Distilled and Extracted Products of Sage (Salvia officinalis L.). Journal of Essential Oil-Bearing Plants, 16(1), 39-44. https:// doi.org/10.1080/0972060X.2013.764175

Bayramoglu, B., Sahin, S. and Sumnu, G. (2008). Solvent-free microwave extraction of essential oil from oregano. Journal of Food Engineering, 88(4), $535-540$. https://doi.org/10.1016/ j.jfoodeng.2008.03.015

Catty, S. (2001). Hydrosols: The Next Aromatherapy. Vermont, USA: Healing Arts Press.

Che Radzi, N.H., Zahari Harip, M.K., Musa, M., Md Zaki, N.A., Alwi, H., Muhd Rodhi, M.N. and $\mathrm{Ku}$ Hamid, K.H. (2018). Analysis of sesquiterpenes in agarwood essential oil from hydrodistillation process. Malaysian Journal of Analytical Sciences, 22(2), 353-357. https://doi.org/10.17576/mjas-20182202-23

Chen, H.-Q., Wei, J.-H., Yang, J.-S., Zhang, Z., Yang, Y., Gao, Z.-H., Sui, C. and Gong, B. (2012). Chemical Constituents of Agarwood Originating from the Endemic Genus Aquilaria Plants. Chemistry and Biodiversity, 9(2), 236-250. https:// doi.org/10.1002/cbdv.201100077

Chua, L.S.L. (2008). Agarwood (Aquilaria malaccensis) in Malaysia. NDF Workshop case studies, WG1 Trees, Case study 3. Retreived from website: https:// cites.org/sites/default/files/ndf_material/WG1-CS3S.pdf

D'Amato, S., Serio, A., López, C.C. and Paparella, A. (2018). Hydrosols: Biological activity and potential as antimicrobials for food applications. Food Control, 86, 126-137. https://doi.org/10.1016/ j.foodcont.2017.10.030

Demirbolat, I., Ekinci, C., Nuhoglu, F., Kartal, M., Yildiz, P. and Gecer, M.O. (2019). Effects of Orally Consumed Rosa damascena Mill. Hydrosol on Hematology, Clinical Chemistry, Lens Enzymatic Activity, and Lens Pathology in StreptozotocinInduced Diabetic Rats. Molecules, 24(22), 4069. https://doi.org/10.3390/molecules24224069

Elias, M.F., Ibrahim, H. and Mahamod, W.R.W. (2017). A Review on the Malaysian Aquilaria species in Karas Plantation and Agarwood Production. International Journal of Academic Research in Business and Social Sciences, 7(4), 1021-1029. https://doi.org/10.6007/IJARBSS/v7-i4/2911

Faborode, M.O. and Favier, J.F. (1996). Identification and Significance of the Oil-point in Seed-oil Expression. Journal of Agricultural Engineering Research, 65(4), 335-345. https://doi.org/10.1006/ jaer.1996.0107

Garneau, F., Collin, G. and Gagnon, H. (2014). Chemical composition and stability of the hydrosols obtained during essential oil production. The case of Melissa officinalis L. and Asarum canadense L. American Journal of Essential Oils and Natural Products, 2(1), 54-62.

Gulec, A.K., Altinterim, B. and Aksu, Ö. (2013). Determination of lethal concentration (LC 50) values of Cinnamomum zeylanicum hydrosol on carp fish. Iranian Journal of Fisheries Sciences, 12(1), 34-44.

Hamedi, A., Moheimani, S.M., Sakhteman, A., Etemadfard, H. and Moein, M. (2017). An Overview on Indications and Chemical Composition of Aromatic Waters (Hydrosols) as Functional Beverages in Persian Nutrition Culture and Folk Medicine for Hyperlipidemia and Cardiovascular Conditions. Journal of Evidence-Based Complementary and Alternative Medicine, 22(4), 544-561.

https:// doi.org/10.1177/2156587216686460

Hussein, A., Gameil, M., Zuhanis, Y., Hashim, H., Aimi, N., Zainurin, A., Mohd, H. and Syed, N. (2019). Anticancer potential and chemical profile of agarwood hydrosol. Malaysian Journal of Fundamental and Applied Sciences, 15(5), 761-766. 
Jok, V.A., Radzi, N.C. and Hamid, K.H.K. (2015). Agarwood Oil Yield As A Result of Changes in Cell Morphology Due To Soaking Process. Procedia Social and Behavioral Sciences, 195, 2443-2450. https://doi.org/10.1016/j.sbspro.2015.06.387

Kalra, R. and Kaushik, N. (2017). A review of chemistry, quality and analysis of infected agarwood tree (Aquilaria sp.). Phytochemistry Reviews, 16(5), 1045-1079. https://doi.org/10.1007/s11101-0179518-0

Kusuma, H.S. and Mahfud, M. (2016). Response surface methodology for optimization studies of microwaveassisted extraction of sandalwood oil. Journal of Materials and Environmental Science, 7(6), 19581971.

Lange, C., Martin, C., Chabanet, C., Combris, P. and Issanchou, S. (2002). Impact of the information provided to consumers on their willingness to pay for Champagne: Comparison with hedonic scores. Food Quality and Preference, 13(7-8), 597-608. https://doi.org/10.1016/S0950-3293(02)00059-9

Liao, G., Dong, W. H., Yang, J. L., Li, W., Wang, J., Mei, W. L. and Dai, H. F. (2018). Monitoring the chemical profile in agarwood formation within one year and speculating on the biosynthesis of 2-(2phenylethyl)chromones. Molecules, 23(6), 1261. https://doi.org/10.3390/molecules23061261

Nor Azah, M., Chang, Y.S., Mailina, J., Abu Said, A., Abd. Majid, J., Saidatul Husni, S., Nor Hasnida, H. and Nik Yasmin, Y. (2008). Comparison of chemical profiles of selected Gaharu oils from peninsular Malaysia. The Malaysian Journal of Analytical Sciences, 12(2), 338- 340.

Pornpunyapat, J., Chetpattananondh, P. and Tongurai, C. (2011). Mathematical modeling for extraction of essential oil from Aquilaria Crassna by hydrodistillation and quality of agarwood oil. Bangladesh Journal of Pharmacology, 6(1), 18-24. https://doi.org/10.3329/bjp.v6il.7902

Rao, B.R.R. (2012). Hydrosols and water-soluble essential oils of aromatic plants: Future economic products. Indian Perfumer, 56(3), 29-33.

Rose, J. (1999). 375 essential oils and hydrosols. USA: North Atlantic Books.

Sağdiç, O. and Özcan, M. (2002). Antibacterial activity of Turkish spice hydrosols. Food Control, 14(3), 141 -143. https://doi.org/10.1016/S0956-7135(02)000579

Sagdic, O., Ozturk, I. and Tornuk, F. (2013). Inactivation of non-toxigenic and toxigenic Escherichia coli O157:H7 inoculated on minimally processed tomatoes and cucumbers: Utilization of hydrosols of
Lamiaceae spices as natural food sanitizers. Food Control, 30(1), 7-14. https://doi.org/10.1016/ j.foodcont.2012.07.010

Samadi, M., Abidin, Z.Z., Yunus, R., Awang Biak, D.R., Yoshida, H. and Lok, E.H. (2017). Assessing the kinetic model of hydro-distillation and chemical composition of Aquilaria malaccensis leaves essential oil. Chinese Journal of Chemical Engineering, 25(2), 216-222. https:// doi.org/10.1016/j.cjche.2016.09.006

Stratakos, A.C. and Koidis, A. (2016). Chapter 4 Methods for extracting essential oils. In Preedy, V.R. (Ed.) Essential Oils in Food Preservation, Flavor and Safety. $1^{\text {st }}$ ed., p. 31-38. USA: Academic Press. https://doi.org/10.1016/B978-0-12-416641-7.000043

Sulaiman, N., Idayu, M.I., RamLan, A.Z., Fashya, M.N., Farahiyah, A.N.N., Mailina, J. and Azah, M.A.N. (2015). Effects of extraction methods on yield and chemical compounds of gaharu (Aquilaria malaccensis). Journal of Tropical Forest Science, 27 (4), 413-419.

Trevisanato, S.I. and Kim, Y.-I. (2000). Tea and health. Nutrition Reviews, 58(1), 1-10. https:// doi.org/10.1111/j.1753-4887.2000.tb01818.x

Wojdyło, A., Oszmiański, J. and Czemerys, R. (2007). Antioxidant activity and phenolic compounds in 32 selected herbs. Food Chemistry, 105(3), 940-949. https://doi.org/10.1016/j.foodchem.2007.04.038

Wu, Z.Q., Liu, S., Li, J.F., Li, M.C., Du, H.F., Qi, L. K. and Lin, L. (2017). Analysis of gene expression and quality of agarwood using agar-bit in Aquilaria sinensis. Journal of Tropical Forest Science, 29(3), 380-388.

https://doi.org/10.26525/ jtfs2017.29.3.380388

Zainurin, N.A.A., Hashim, Y.Z.H.Y., Mohamed Azmin, N.F. and Al-Khatib, M.F.R. (2020). Understanding the effects of different parameters of soxhlet extraction on bioactive compounds from Aquilaria malaccensis leaf through GCMS-based profiling. Food Research, 4(Suppl. 1), 63-73. https:// doi.org/10.26656/fr.2017.4(S1).S09

Zakaria, F., Talip, B.A., Kahar, E.E.M., Muhammad, N., Abdullah, N. and Basri, H. (2020). Solvent used in extraction process of agarwood: A systematic review. Food Research, 4(3), 731-737. https:// doi.org/10.26656/fr.2017.4(3).333

Zheljazkov, V.D., Astatkie, T. and Schlegel, V. (2014). Hydrodistillation Extraction Time Effect on Essential Oil Yield, Composition, and Bioactivity of Coriander Oil. Journal of Oleo Science, 63(9), 857865. https://doi.org/10.5650/jos.ess 14014 